\title{
Application of ICT-Based Learning Model for Tahfidz Islam Islamic Private Junior High School Teachers
}

\author{
Penerapan Model Pembelajaran Berbasis TIK Bagi Guru-Guru SMP \\ Swasta Islam Tahfidz
}

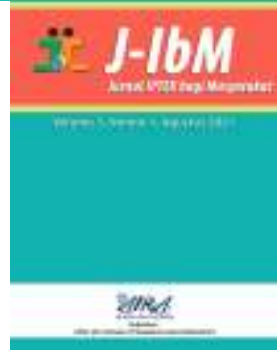

\author{
Zulkarnain Sirait*, Guntur Maha Putra, Akmal \\ Sekolah Tinggi Manajemen Informatika dan Komputer Royal; Kisaran; Indonesia; 21222; \\ *Correspondence: zulkarnainsrt123@gmail.com; \\ https:journal.aira.or.id/J-IbM | \\ Submission Received : 13-12-2021; Revised : 19-12-2021; Accepted : 21-12-2021; Published : 29-12-2021
}

\begin{abstract}
The application of the learning model is one of the means to support the achievement of learning implementation by utilizing an organized and coordinated method to be delivered to students. The development of learning models is also the work of a teacher to achieve the objectives of a discussion on the material to be conveyed so that it is lighter and easier for students to understand. Developments in modernity today are Information and Communication Technology, Improvement of, all things considered, can be obtained through technology. Technology is used as a learning model in a more modern and innovative world of education. One of the applications used in the Information and Communication Technology (ICT)-based learning model is Google Classroom which can make students easily access all sources of learning information, therefore Information and Communication Technology can make it easier for teachers and students to find and dig up information on various sciences.
\end{abstract}

Keywords: Learning Model, ICT-Based, Google Classroom.

Abstrak: Penerapan model pembelajaran merupakan salah satu sarana untuk mendukung tercapainya pelaksanaan pembelajaran dengan memanfaatkan metode yang terorganisir dan terkoordinasi untuk disampaikan kepada siswa. Pengembangan Model pembelajaran juga merupakan karya seorang guru untuk mencapai tujuan dari suatu pembahasan pada materi yang ingin disampaikan agar lebih ringan dan mudah dipahami siswa. Perkembangan dalam modernitas saat ini merupakan Teknologi Informasi dan Komunikasi, Peningkatan semua hal dipertimbangkan, dapat diperoleh melalui teknologi. Teknologi dimanfaatkan sebagai model pembelajaran dalam dunia pendidikan yang lebih moderen dan inovatif. Salah satu aplikasi yang digunakan pada model pembelajaran berbasis Teknologi Informasi dan Komunikasi (TIK) adalah Google Classroom yang dapat membuat siswa dengan mudah mengakses segala sumber informasi pembelajaran, maka dari itu Teknologi Informasi dan Komunikasi dapat mempermudah guru maupun siswa mencari dan menggali informasi berbagai ilmu pengetahuan.

Kata Kunci: Model Pembelajaran, Berbasis TIK, Google Classroom 
Page 82 of 9 | J-IbM: Jurnal IPTEK bagi Masyarakat, Volume 1, Nomor 2, Desember 2021

\section{Pendahuluan}

Menurut Sudjana Nana (2021), Belajar merupakan suatu proses yang ditandai dengan adanya pola perubahan pada diri manusia . Belajar menurut Morgan (2021), adalah perubahan sikap yang bersifat tahan lama sebagai hasil dari pengalaman. Salah satu tanda bahwa seseorang telah menguasai sesuatu adalah penyesuaian perilaku dalam dirinya.

Suprijono (2007) mengatakan Perubahan tingkah laku ini meliputi perubahan pengetahuan (kognitif), kemampuan (psikomotor) serta perubahan nilai dan sikap (afektif). Belajar tidak hanya memasukkan mata pelajaran, tetapi juga otoritas, kecenderungan, wawasan, kegembiraan, kemampuan, perubahan sosial, berbagai kemampuan, dan keinginan.

Perkembangan Teknologi Informasi dan Komunikasi yang pesat mempengaruhi kebutuhan akan media pembelajaran berbasis TIK tidak dapat terelakkan (Kurniawan, D 2013). Hal ini sangat membantu dan memudahkan bagi penggunanya dalam menjalankan kegiatan belajar mengajar. Selama situasi pandemi covid 19 kegiatan pembelajaran dituntut dengan menggunakan pola dan model pembelajaran yang berbeda dari seperti biasanya yaitu dilakukan secara daring yang memungkinkan bagi penggunanya menggunakan komputer, laptop, smartphone dalam proses belajar mengajar.

Jelas bagi siswa, pedoman ini akan mengganggu siklus belajar mereka, terutama karena banyak siswa berada di tahun terakhir sekolah mereka saat ini, siswa membutuhkan lebih banyak waktu untuk dapat mempelajari ujian terakhir yang akan mereka hadapi. Semua hal akan dipertimbangkan, siswa juga harus terus belajar meskipun secara daring. Guru dituntut berinovasi dalam mengajari siswa-siwanya. Dengan penggunaan proses belajar mengajar yang berbeda ini, maka mengharuskan guru dan siswa untuk memilih motede belajar yang digunakan selama pembelajaran jarak jauh berlangsung.

Arah pendidikan saat ini diperlukan untuk menumbuhkan pendekatan pembelajaran sesuai dengan pedoman pendidikan Negara kita yang bersumber pada UUD 1945 dan UU no. 20 Tahun 2003 (Depdiknas) yang ditetapkan pada nilai-nilai agama, kebudayaan, Ilmu Pengetahuan dan Teknologi (IPTEK).

Pendampingan pelatihan saat ini diperlukan untuk menumbuhkan pendekatan pembelajaran yang sesuai dengan unsur-unsur sistem negara kita yang telah diamanatkan dalam UUD 1945 dan UU No. 20 Tahun 2003 yang ditetapkan dalam kualitas sosial, permintaan kesempatan dan perbaikan yang ketat.

Sistem pembelajaran harus cerdas, bergerak, menyenangkan, menguji, membujuk siswa untuk mengambil bagian secara efektif, dan memberikan ruang yang cukup untuk mendorong, kreativitas, dan kemandirian yang ditunjukkan oleh kemampuan minat serta bakat siswa. Sistem pembelajaran harus mencakup banyak kelompok, yang disesuaikan dengan kemajuan mekanis untuk bekerja dengan pencapaian suasana tertentu dalam sistem pembelajaran sehingga siswa nyaman dalam belajar.

Teknik pembelajaran jarak jauh ini mendorong siswa untuk belajar lebih mandiri dan siswa lebih berani dalam mengemukakan pandangan dan pemikirannya (Ismawati dan Prasetyo, 2020; Sadikin dan Hamidah, 2020). Kemudian lagi, teknik pembelajaran ini menghadapi kesulitan aksebilitas pada kantor untuk membantu pelaksanaan latihan 
pembelajaran jarak jauh, misalnya, gadget untuk menuju media pembelajaran seperti PC/komputer atau ponsel, hingga bantuan keuangan untuk membeli bundel informasi web (Hidayat, Anisti, Purwadhi, dan Wibawa, 2020). Untuk dukungan gadget, Anda bisa memilih aplikasi yang bisa diakses melalui ponsel karena lebih banyak mahasiswa yang memiliki ponsel (Handarini dan Wulandari, 2020).

Sekolah Menengah Pertama Swasta Islam Tahfidz Kecamatan Kisaran Timur merupakan salah satu sekolah yang terdampak dari virus covid 19 yang membuat para guru dan siswa harus mengganti pola dalam memberikan bahan ajar. Permasalahan yang terjadi saat ini adalah belum adanya informasi mengenai media yang dapat digunakan dalam proses pembelajaran selama terjadinya virus covid 19 yang mewajibkan para siswa belajar dari jarak jauh menggunakan media yang dapat dimanfaatkan pada proses pembelajaran. Berkaitan dengan hal tersebut di atas maka pada saat ini, diperlukan persiapan bagi para pendidik untuk memiliki pilihan untuk membantu dan bekerja dengan pekerjaan mereka selama pembelajaran daring berlangsung.

Berdasarkan permasalahan tersebut, kelompok pengabdian yang merupakan dosen dari STMIK ROYAL Kisaran bergerak cepat melaksanakan kegiatan pelatihan dengan Tema "Penerapan model pembelajaran berbasis TIK bagi guru-guru SMP Swasta Islam Tahfidz" di Kecamatan Kisaran Timur. Salah satu sarana aplikasi yang digunakan pada penerapan model pembelajaran berbasis TIK adalah Google Classroom sebagai media dalam belajar mengajar antara siswa dan guru.

Google Classroom yaitu merupakan aplikasi dari pengembangan teknologi yang harus digunakan dalam pembelajaran pada situasi pandemi covid 19. Google Classroom merupakan aplikasi berbasis internet yang dapat dimanfaatkan secara gratis. Guru dapat membuat kelas mereka sendiri dan memberikan kode kelas kepada siswa. Google Classroom diharapkan dapat membantu guru dan siswa dalam mengatasi kesulitan belajar, memberi materi, dan mengerjakan tugas tanpa harus pergi ke kelas.

Tujuan utama Google Classroom adalah untuk memudahkan cara paling umum membagi dokumen di antara guru dan siswa. Google Classroom menggabungkan Google Drive untuk pembuatan dan penyampaian tugas, Google Dokumen, Spreadsheet, Slide untuk menulis, Gmail untuk korespondensi, dan Google Kalender untuk penjadwalan. Siswa dapat dipersilakan untuk bergabung dengan kelas melalui kode pribadi, atau secara alami diimpor dari lingkungan sekolah. Setiap kelas membuat pengelola yang berbeda di setiap drive masing-masing siswa, di mana siswa dapat mengirimkan tugas untuk dinilai oleh guru. Aplikasi ini dapat diakses oleh siswa dari gadget iOS dan Android yang memungkinkan siswa untuk mengambil foto dan melampirkan tugas, berbagi catatan dari aplikasi lain dan mengakses informasi tidak online. Guru dapat menilai kemajuan dari setiap siswa, dan untuk dapat dievaluasi. Dengan adanya googleclassroom diharapkan penggunaannya menjadi semakin efektif seiring dengan berkembangnya teknologi dan metode pembelajaran yang digunakan (Hardhono, 2002).

Sarana adalah segala sesuatu yang dapat dimanfaatkan sebagai alat dalam mencapai maksud dan tujuan, alat serta media. sedangkan informasi merupakan data yang diolah menjadi bentuk yang lebih berguna dan lebih berarti bagi yang menerimanya. Informasi sebagai hasil dari pengolahan data dalam suatu bentuk yang lebih berguna dan lebih berarti bagi penerimanya yang menggambarkan suatu kejadian-kejadian yang nyata yang digunakan untuk pengambilan keputusan (Mujiati \& Sukadi, 2016). 


\section{Metode}

Kegiatan Pelatihan ini berlangsung pada tanggal 27-28 Agustus 2021 di Aula SMP Swasta Islam Tahfidz Kecamatan Kisaran Timur yang diikuti oleh para guru sebanyak 24 orang. Pelaksanaan kegiatan ini berlangsung dengan cara memberikan pelatihan bagi para guru, yaitu berupa penyampaian materi model pembelajaran berbasis TIK, kemudian dilanjutkan dengan memanfaatkan aplikasi Google Classroom pada media informasi dalam hal ini memanfaatkan PC/Laptop maupun Smartphone/Android masing-masing peserta. Pada kesempatan ini peserta pelatihan memanfaatkan forum tanya jawab serta diskusi.
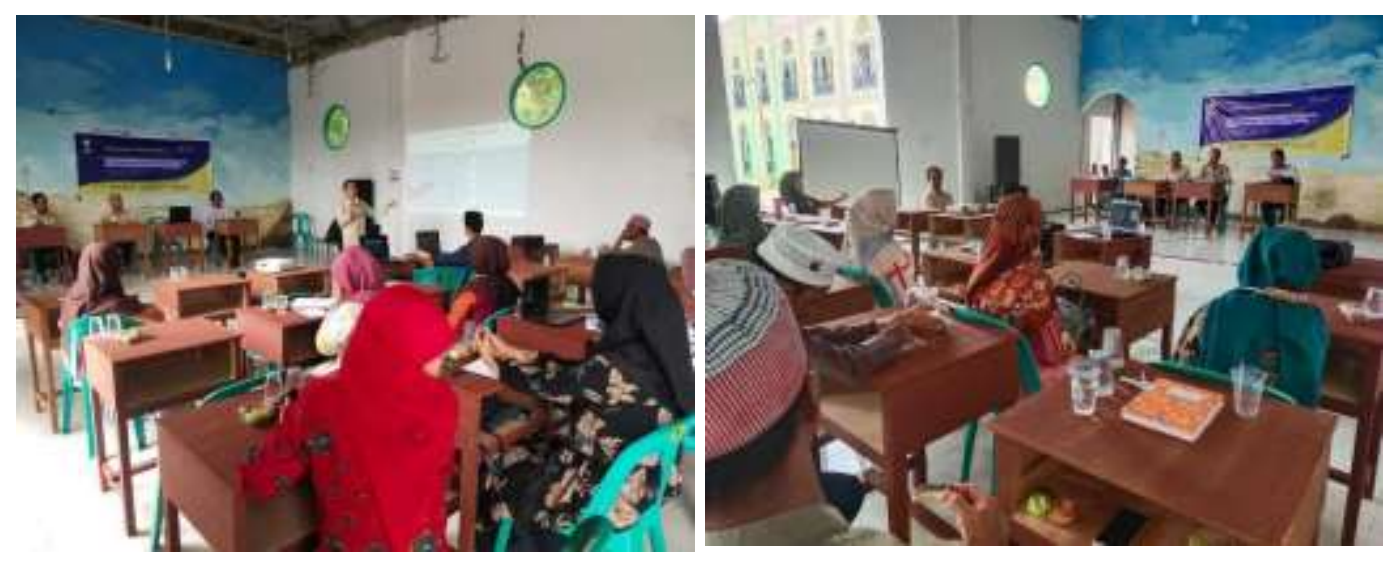

Gambar 1. Pemaparan materi kepada para Guru SMP. Swasta Islam Tahfidz

Kelompok pengabdian memberikan panduan singkat untuk melaksanakan dasar pendirian dan aktivitas dari aplikasi Google Classroom yang merupakan tahap persiapan. Peserta pelatihan juga dapat menghubungi panitia agar dapat dibantu secara teknis dalam mempraktekkan atau menjalankan aplikasi. Pada saat pelaksanaan, dilakukan kegiatan pre-test kepada peserta pelatihan sehubungan dengan pemahaman peserta pelatihan tentang tahapan yang akan diinstruksikan dalam persiapan ini. Kegiatan selanjutnya adalah pengenalan materi yang diisi oleh kelompok pengabdian dosen-dosen dari STMIK ROYAL Kisaran, dan praktek yang diikuti oleh para peserta pelatihan. Modul materi diserahkan kepada setiap peserta pelatihan sehingga diharapkan mampu mengikuti materi yang disampaikan. Kegiatan ini diakhiri dengan post-test kepada peserta pelatihan. Seluruh rangkaian kegiatan pelatihan ditutup dengan kegiatan evaluasi. Evaluasi ini dilakukan secara online dan diikuti oleh seluruh panitia pelaksana. Dalam Evaluasi Ini digambarkan mengenai hasil dari post-test dan timbal balik peserta pelatihan terhadap kegiatan pelatihan. Selain itu, analisis dan gagasan tentang pelaksanaan khusus persiapan ini juga diteruskan. 


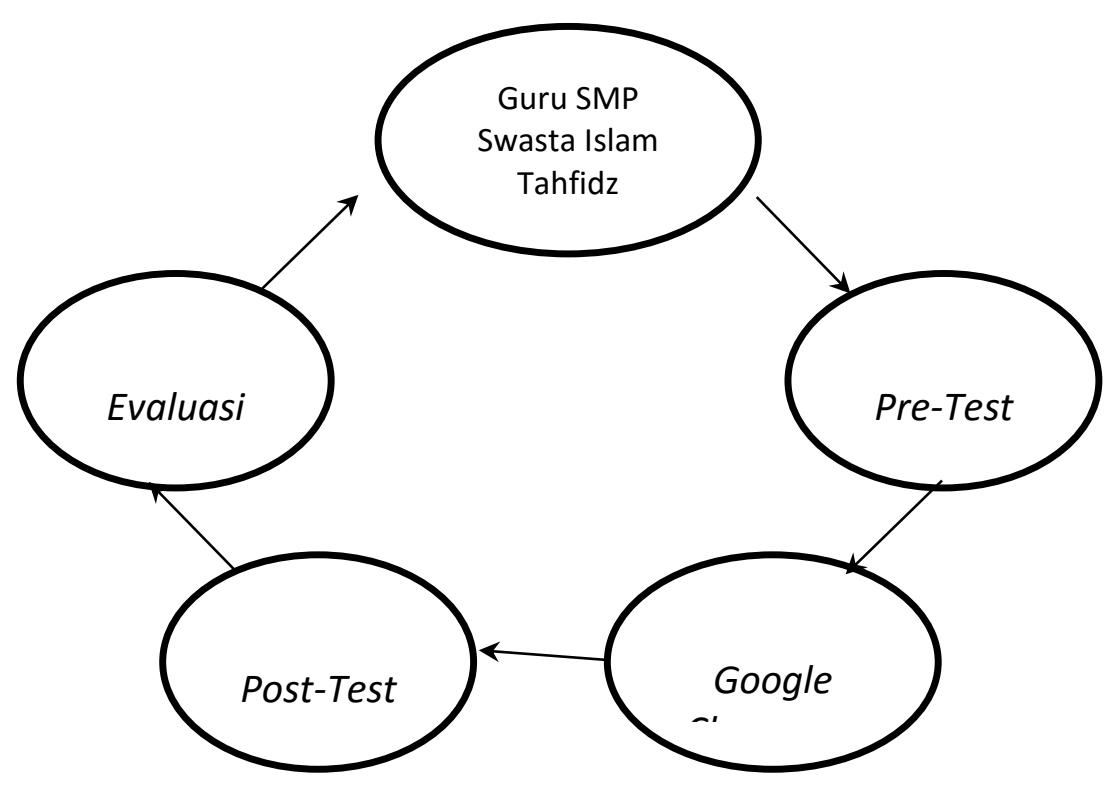

Gambar 2. Metode Pelaksanaan Pengabdian Kepada Masyarakat

\section{Hasil}

Berdasarkan wawancara, diskusi dan pengamatan secara langsung selama kegiatan pengabdian kepada masyarakat tini, memberikan hasil sebagai berikut :

1. Terjadinya peningkatan pengetahuan dalam penggunaan model pembelajaran berbasis TIK menggunakan aplikasi Google Classroom sebagai media dalam kegiatan belajar mengajar di SMP Swasta Islam Tahfidz Kecamatan Kisaran Timur Kabupaten Asahan.

2. Meningkatnya kemampuan guru -guru SMP Swasta Islam Tahfidz Kecamatan Kisaran Timur Kabupaten Asahan dalam menggunakan aplikasi Google Classroom dalam sistem pembelajaran di masa pandemi covid 19.

Sebagai hasil kegiatan PKM ini maka kita bisa melihat table 1 dimana menunjukan nilai hasil peran serta guru-guru SMP Swasta Islam Tahfidz dalam kegiatan Pengabdian Masyarakat ini.

Tabel.1 Hasil Pencapaian Penerapan model pembelajaran berbasis tik bagi Guru-guru SMP Swasta Islam Tahfidz Kecamatan Kisaran Timur Kabupaten Asahan

\begin{tabular}{|c|l|c|}
\hline No & \multicolumn{1}{|c|}{ Uraian } & Skor Akhir \\
\hline 1 & Penguasaan memahami materi Kegiatan & 90 \\
\hline 2 & $\begin{array}{l}\text { Keinginan menjalankan Aplikasi Google Classroom dalam } \\
\text { pembelajaran }\end{array}$ & 85 \\
\hline 3 & Kemampuan penggunaan pada aplikasi Google Classroom & 90 \\
\hline 4 & Tingkat ketepatan & 85 \\
\hline
\end{tabular}




\begin{tabular}{|l|l|l|}
\hline No & \multicolumn{1}{|c|}{ Uraian } & Skor Akhir \\
\hline Keterangan: & \\
Guru -guru memiliki nilai 90 menunjukan penguasaan sangat baik & \\
Guru-guru memiliki nilai 85 menunjukan penguasaan baik & \\
\hline
\end{tabular}

\section{Diskusi}

Pelaksanaan pengabdian masyarakat dengan tema "Penerapan model pembelajaran berbasis TIK Bagi guru-guru SMP Swasta Islam Tahfidz" ini telah dilaksanakan sesuai dengan jadwal dan berjalan dengan lancar. Besarnya dukungan dari berbagai pihak baik dari lingkungan kampus STMIK Royal melalui Lembaga Penelitian dan Pengabdian Masyarakat serta pihak dari Kepala Sekolah maupun guru di SMP Swasta Islam Tahfidz.

Dari hasil pelaksanaan pelatihan yang telah dilakukan kepada para guru dirasakan sangat bermanfaat. Hal tersebut berdasarkan hasil pengamatan dan wawancara langsung kepada para guru yang mengikuti kegiatan tersebut merasakan mendapatkan banyak ilmu pengetahuan dan pengalaman yang nantinya akan diaplikasikan kepada para siswa dalam proses pembelajaran.

Bahan materi yang disajikan dalam pengabdian kepada masyarakat dirancang sesuai dengan tujuan yang akan dicapai nantinya.

Adapun tahapannya adalah sebagai berikut:

a. Memberikan materi modul kepada seluruh peserta pelatihan kegiatan Pengabdian Masyarakat

b. Narasumber Menjelaskan apa itu Google Classroom, fasilitas apa saja yang terdapat pada Google Classroom beserta kelebihan aplikasi Google Classroom.

c. Kemudian, para peserta yaitu para pendidik/guru memahami cara penggunaan Google Classroom yang dapat dilakukan Work From Home selama pembelajaran daring berlangsung.

Materi dari kegiatan adalah sebagai berikut:

a. Buka situs aplikasi peramban website (browser) di Komputer/PC atau laptop Anda. Buka laman https://classroom.google.com/h?hl=id

b. Klik tombol "Buka Kelas” untuk masuk ke halaman login Akun Google.

c. Kemudian akan diarahkan ke halaman konfirmasi mengenai persetujuan syarat dan ketentuan layanan Google. Klik tombol “Terima” untuk melanjutkan.

d. Klik tombol "Lanjutkan" untuk mulai menggunakan "Classroom".

e. Selanjutnya, akan diminta memilih peran sebagai seorang siswa atau pengajar. Jika Anda seorang siswa, klik "Saya seorang siswa" dan Anda akan diarahkan ke halaman arahan kelas. 
f. Kemudian, daftar atau join kelas dengan cara tap tanda “+” (perhatikan tanda panah) dan klik "Gabung dengan kelas", masukkan kode kelas yang terdapat pada lembar rencana tugas sesuai kelas atau mata pelajaran yang akan diikuti.

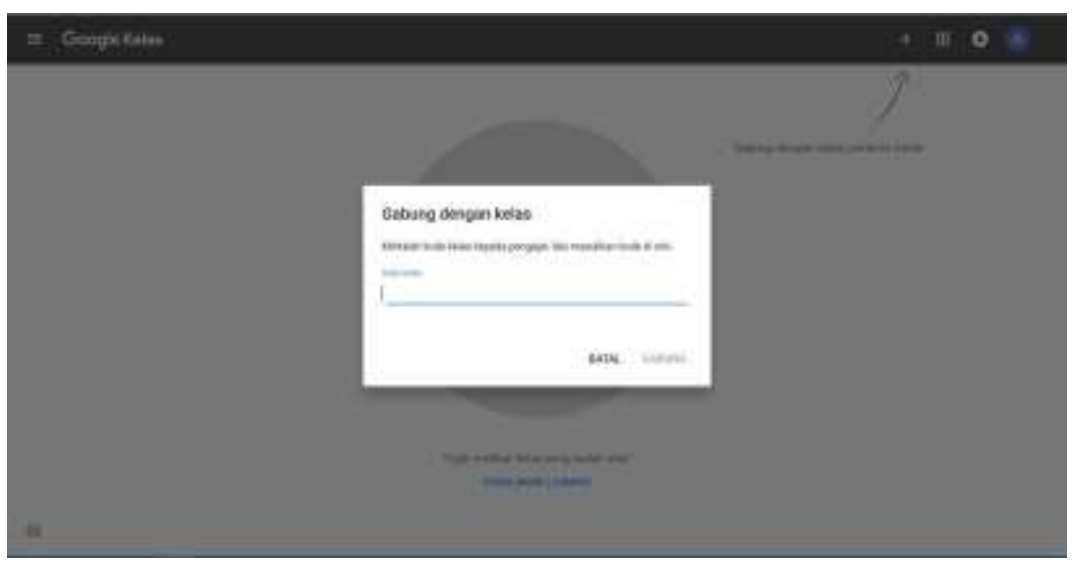

Gambar 2. Tampilan Siswa pada saat ingin bergabung dengan kelas

g. Jika berhasil, akan dikoordinasikan ke halaman dashboard kelas. Untuk memasukan kode kelas lain, klik menu $\equiv$, pilih "kelas". Lakukan cara yang sama untuk memasukan kode kelas lainnya.

h. Apabila berperan sebagai pengajar, klik "saya seorang pengajar".

i. Setelah memilih peran sebagai pengajar maka akan diarahkan ke dalam laman Google Classroom. Untuk membuat kelas, klik tanda "+" di sudut kanan atas dan klik "create class" atau "buat kelas".

j. Untuk bagian Class Name dapat mengisi dengan nama mata pelajaran yang diampu, misal Bahasa Indonesia, untuk bagian Section adalah nama kelasnya Kelas A, untuk bagian Subject dapat mengisi dengan semester, dan untuk bagian Room dapat Anda isi ruang kelas. Untuk menambahkan kelas dapat klik tanda "+" lagi. Jika ingin mengedit nama kelas dapat klik tanda titik tiga di sebelah kanan atas dari kelas.

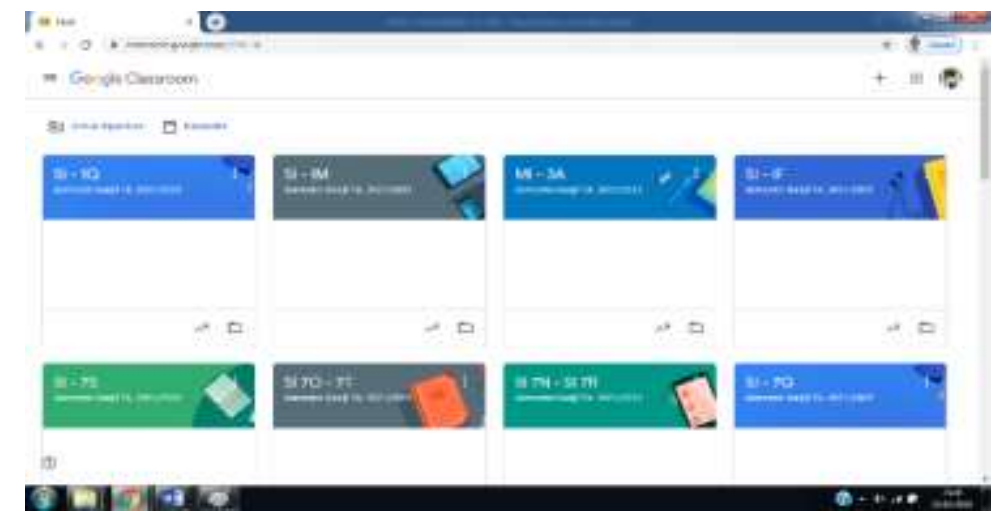

Gambar 3. Tampilan daftar kelas pada google classroom 
Setelah diarahkan oleh Narasumber dan tim untuk membuat akun "Google Classroom". Untuk mempermudah guru dalam mengelola kelas ketika pembelajaran, guru segera membuat akun Google Classroom. Para guru sangat antusias untuk membuat Google Classroom. Hal Ini terlihat dari setiap guru membuat akun dan menanyakan kepada narasumber dan tim ketika menghadapi kendala dalam pembuatan akun Google Classroom mereka. Para guru dapat dengan mudah melihat dan memeriksa hasil tugas siswa tanpa harus membawa banyak kertas. Kemudian, para siswa juga lebih mudah untuk melihat hasil penilaian yang diberikan guru, karena Google Classroom dapat diakses dimana saja, tidak hanya disekolah maupun di rumah.

Kemudian dari hasil pertemuan dengan guru, Google Classroom mampu membuat data lebih terintegrasi. Jadi pendidik tidak akan lalai untuk menyimpan data siswa ketika siswa telah menyelesaikan tugas, karena semua data disimpan dalam akun google. Hal ini dapat membuat belajar lebih efisien dan efektif. Pendidik juga dapat segera menjelaskan bila ada siswa yang kurang paham.

Penggunaan Google Classroom juga mendukung program pemerintah dalam membuat langkah menuju ramah lingkungan. Hal ini terlihat dengan mengurangi penggunaan kertas yang digunakan dalam mengumpulkan tugas, sehingga secara tidak langsung penggunaan Google Classroom membantu dalam menjaga lingkungan. Namun, menggunakan Google Classroom membutuhkan koneksi internet yang baik saat kita menggunakannya. Oleh karena itu, kantor-kantor di sekolah juga harus didukung dengan sarana internet yang bagus agar Google Classroom dapat digunakan oleh para pendidik dan siswa.

Secara umum, pelaksanaan pelatihan kegiatan bagi para guru berjalan dengan baik dan lancar. Hal ini menunjukkan bahwa persiapan ini memberikan manfaat bagi para guru dan membantu mereka dalam melaksanakannya di ruang belajar. Ini bermaksud untuk bekerja pada sifat pembelajaran untuk mencapai tujuan pembelajaran. Hal ini sesuai dengan hipotesisnya bahwa pemanfaatan teknologi sangat berpengaruh terhadap pembelajaran (Megahantara, 2017).

\section{Kesimpulan}

Berdasarkan penjelasan di atas, maka dapat disimpulkan bahwa penerapan model pembelajaran berbasis TIK bagi guru-guru SMP Swasta Islam Tahfidz dengan menggunakan aplikasi Google Classroom memberikan manfaat yang sangat besar bagi para guru. Guru sangat aktif dan antusias dalam menggunakan Google Classroom, guru mengetahui aplikasi yang dapat mereka gunakan dalam pembelajaran, guru dapat lebih efektif mengawasi kelas, menghemat waktu, dan memberikan panduan kepada siswa untuk menjaga lingkungan dengan mengurangi penggunaan kertas. Meski demikian, fasilitas seperti ketersediaan koneksi internet yang baik juga harus didukung oleh setiap sekolah. Karena dengan fasilitas yang baik dapat mempermudah pemakai akun Google Classroom. Hal ini sesuai dengan tuntutan pendidikan pada masa Society 5.0. Sehingga, diperlukan kerjasama yang baik, agar kreatifitas guru tercapai dengan kualitas pembelajaran yang lebih bermutu. 


\section{Pengakuan}

Kami mengucapkan terima kasih dan penghargaan kepada seluruh rekan-rekan yang turut berpartisipasi dalam kegiatan ini, kepada Ketua STMIK Royal Kisaran yang telah memberikan arahan dan inspirasi dalam kegiatan ini, tidak lupa juga kami ucapkan terima kasih kepada Ketua LPPM STMIK Royal atas arahan dan bantuannya dalam kegiatan ini. Sehingga dapat berjalan sesuai dengan yang diharapkan, kemudian penghargaan yang setinggi-tingginya disampaikan kepada Kepala Sekolah SMP Swasta Islam Tahfidz dan juga kepada para guru yang telah memberikan kepercayaan penuh atas terselenggaranya kegiatan Pengabdian kepada Masyarakat yang berlangsung dengan lancar dan berkesinambungan.

\section{Daftar Referensi}

A. Hardhono. (2002) "Potensi Teknologi Komunikasi dan Informasi dalam Mendukung Penyelenggaraan Pendidikan Jarak Jauh di Indonesia.," Jurnal Pendidikan Terbuka dan Jarak Jauh. Pusat Studi Indonesia, Lembaga Penelitian Universitas Terbuka., vol. 3, no. 1, pp. 112-126.

A. Suprijono. (2007). Cooperative Learning : Teori dan Aplikasi PAIKEM., Yogyakarta: Pustaka Pelajar.

C. T. Morgan. (2001) Introduction to Psychology, New York: Kogakusha: Mc Graw-Hill.

Depdiknas. (2003). Undang-undang RI No.20 tahun 2003. tentang sistem pendidikan nasional.

Handarini, O. I., \& Wulandari, S. S. (2020). Pembelajaran Daring Sebagai Upaya Study From Home (SFH) Selama Pandemi Covid 19. Jurnal Pendidikan Administrasi Perkantoran (JPAP), 8(3), 2020. Retrieved from https://journal.unesa.ac.id/index. php/jpap

Hidayat, D., Anisti, Purwadhi, \& Wibawa, D. (2020). Crisis Management and Communication Experience in Education during the COVID-19 Pandemic in Indonesia. Jurnal Komunikasi: Malaysian Journal of Communication Jilid, 36(3), 2020. https://doi.org/10.17576/JKMJC-2020-3603-05

Ismawati, D., \& Prasetyo, I. (2020). Efektivitas Pembelajaran Menggunakan Video Zoom Cloud Meeting pada Anak Usia Dini Era Pandemi Covid-19. Jurnal Obsesi : Jurnal PendidIkan Anak Usia Dini, 5(1), 665. https://doi.org/10.31004/obsesi.v 5i1.671

Kurniawan, D (2013), Teknologi Informasi dan Komunikasi dalam pembelajaran. Jakarta: PT. Rajagrafindo Persada.

Mujiati, H., \& Sukadi. (2016). Analisis Dan Perancangan Sistem Informasi Stok Obat Pada Apotek Arjowinangun. Indonesian Jurnal on Computer Science, 9330(2), 1-6.

N. Sudjana. (2001) Media Pengajaran, Jakarta: Algensindo, Sinar Baru.

Sadikin, A., \& Hamidah, A. (2020). Pembelajaran Daring di Tengah Wabah Covid-19. BIODIK, 6(2), 109-119. https://doi.org/10.22437/bio.v6i2.9759 